\title{
The Origins and Myths of the
}

\section{Swedish Model of Workplace}

\section{Democracy}

\author{
A S T R I D H E D I N
}

\begin{abstract}
In 1976 Sweden adopted a law on workplace democracy, presented by the Social Democratic government as the 'reform of the century'. What can the reform tell us about the history of the Swedish Model and how it was revised during the early 1970 s under the prime minister, Olof Palme? This article compares four grand narratives of the development of welfare states, viewing dominant narratives of the Swedish Model as influential myths in their own right. The article argues that despite its global reputation as a hallmark of 'democratic socialism', the Swedish workplace democracy reform was a broad cross-class compromise, in the wake of a pan-European wave of similarly labelled reforms. Furthermore, the reform served to protect workplaces against Communist activism. The argument builds on the internal meeting protocols of the board and executive committee of the Swedish Social Democratic Party.
\end{abstract}

We could not have imagined that the watchword of equality would have such a terrific impact in Swedish society. It's interesting. It shows that we have a significant problem in modern society. . . Our task is to concretise the debate about equality. We have the state investigation into low income and a committee on equality working, but I think that when we strive towards concretisation on the question of equality, we should steer towards the problems of life in the workplace, because it is there that big steps can be made in the coming years.

Swedish Prime Minister Olof Palme to the Swedish Social Democratic Party board, 4 June $197 \mathrm{I}^{1}$

In 1976 , as the grand finale of a series of radical labour market reforms that redefined the Swedish Model, Sweden adopted a law on Worker Co-Determination in the

Malmö University, Global Political Studies, Malmö, SE-20506, Sweden; astrid.hedin@mah.se

The research for this article was funded by a grant from the Swedish Research Council, Vetenskapsrådet and drafted during a stay as Anna Lindh fellow of the Europe Center at Stanford University. I thank the Stanford Comparative Sociology Workshop, Professors Bo Bengtsson and Sverker Gustavsson at Uppsala University, as well as conference participants of the Axe 2 of the French Lab-ex research programme 'Écrire une histoire nouvelle de l'Europe' (EHNE) for helpful suggestions on the project. I also wish to thank the three anonymous reviewers for comments and criticism.

1 Arbetarrörelsens Arkiv [Swedish Labour Movement Archives], Stockholm, Sveriges Socialdemokratiska Arbetareparti [Sweden's Social Democratic Party], Partistyrelsens protokoll [Protocols of the party board and executive committee], ARBARK I889/A/2/A/I97I, 4 June I97I. (All quotes are translated from Swedish by the author.) 
Workplace, Medbestämmandelagen (MBL). When the law was adopted by parliament in June I976, the prime minister, Olof Palme declared MBL the 'reform of the century' and the most important widening of power and influence since universal suffrage. $^{2}$ What can the MBL reform tell us about the history of the Swedish Model and how it was revised during the early I970s? To this day, the image of Sweden as a middle way or third way between capitalism and socialism still lingers. We compare this narrative to the case of the MBL reform and ask how the balancing act played out on the issue of workplace democracy. Did Sweden find inspiration for the reform from its Communist or from its capitalist neighbours in Europe? Did the reform make the Swedish Model more or less 'socialist'? This article argues that the myth and narrative of the MBL reform was more 'socialist' than its origins and design. The argument is put forward that the MBL reform was characteristic of a bifurcated strategy that the Swedish Social Democratic Party (Socialdemokratiska Arbetarepartiet, SAP) developed during the early I970s, where a pragmatic policy with broad cross-class support was only loosely coupled to an accompanying increasingly radical and ideological rhetoric. This rhetoric, myth or narrative eventually gained a momentum of its own, with effects both on domestic Swedish politics and on the international perception of the Swedish Model.

This article brings to light and, from a non-Marxist perspective, seeks to deconstruct dominating global grand narratives of the Swedish Model, viewing the traditional grand narratives as part of history itself. ${ }^{3}$ The article counterposes two well-known Marxist grand narratives of European history and the evolution of Western European welfare states with an emerging liberal modernisation line of analysis as well as with a fourth and new alternative suggested here, that is inspired by world society studies. The world society perspective emphasises, on the one hand, the importance of international legislative trends and of the international zeitgeist. On the other hand, it highlights how actual policies are often de-coupled from their myth and ceremony. ${ }^{4} \mathrm{MBL}$ was advertised as a radical reform, made to meet the demands of a radicalised climate of opinion in Swedish society, in the aftermath of the world-wide I968 upheavals. However, the actual design and implementation of the Swedish reform was not socialist, but compatible with both capitalism and liberal democracy. This article demonstrates how both the myth and ceremony and the practical implementation of MBL served as a cold war defence against socialism, upholding and improving on capitalism and liberal democracy, albeit under a radical banner. The governing Social Democratic Party (SAP) chose a legislative reform

${ }^{2}$ Kammarens protokoll [Protocols of the Swedish parliament] I975/76: I46, 2 June I976, Arbetsrättsreform m.m. [Labour law reform etc.].

3 Cf. Matthias Middel and Lluis Roura, 'The Various Forms of Transcending the Horizon of National History Writing', in Middell and Roura, eds, Transnational Challenges to National History Writing (Basingstoke: Palgrave Macmillan, 20I3), I-35.

4 John W. Meyer, 'World Society and the Nation State', American Journal of Sociology, IO3, I (I997), I44-8I; John W. Meyer and Brian Rowan, 'Institutionalized Organizations: Formal Structure as Myth and Ceremony', American Journal of Sociology, 83 (I977), 340-63. 
label that was popular in Europe at the time, in both the East and the West - namely worker participation - and moulded it to fit domestic political needs.

Drawing on the internal meeting protocols of the SAP, this article narrates the events leading up to the MBL decision from the perspective of the SAP board and executive committee. It argues that Swedish civil society at the time, as well as the international perception of Sweden's legislative initiative since then, was and has been influenced by myths of worker participation present in the contemporaneous world society. Within the world society at that time (i.e. within international as well as transnational non-governmental organisations, associations, social movements and epistemic communities), worker participation in European Communist regimes was seen as comparable and relevant to the Western European experience, supporting the long-lived myth or image of Swedish workplace democracy as 'socialist'. 5 The four 'analytical cuts' or narrative frameworks seek to make visible the complex provenances and broader European entanglements of the Swedish MBL reform, thereby undermining the dominating one-dimensional master narrative of the Swedish Model as the product of 'class struggle' led by social democracy. ${ }^{6}$

The article begins by introducing the Swedish Model, and the position of the workplace participation reform MBL within it. Then, the four analytical cuts are presented. These four analytical models make different assumptions on where to look for the answers to the following questions: which actors demanded MBL, why did the Swedish government decide to legislate and what were the consequences of the reform? Following their lead gives us four different stories or narratives of MBL and thereby relativises and deconstructs the hitherto dominating myth and grand narrative of MBL and the Swedish Model as the result of successful democratic class struggle.

The classic democratic class struggle narrative reads the Swedish Model as the accomplishment of a well-organised social democracy, consisting of the Social Democratic Party (SAP) and the Swedish trade union confederation, Landsorganisationen (LO). In this vein, Gösta Esping-Andersen's and Walter Korpi’s canonical accounts have dominated research on Scandinavian welfare states for almost four decades. ${ }^{7}$ A more recent contender within welfare state studies is the

5 On the concepts of myth and ceremony employed in this article, see Meyer and Rowan, 'Institutionalized Organizations'.

6 On the concepts of entangled histories and histoire croisée, see Michael Werner and Bénédicte Zimmermann, 'Vergleich, Transfer, Verflechtung: Der Ansatz der Histoire croisée und die Herausforderung des Transnationalen', Geschichte und Gesellschaft, 28, 4 (2002), 607-36; Michel Espagne, 'Sur les limites du comparatisme en histoire culturelle', Genèses, I7, I (I994), II2-2I. On the concept of an analytical cut, see Graham Allison, 'Conceptual Models and the Cuban Missile Crisis', The American Political Science Review, 63, 3 (I969), 680-7i 8, 69I n. I.

7 Walter Korpi, 'Conflict, Power and Relative Deprivation', The American Political Science Review, 68, 4 (I974), I569-78; 'Power Resources Approach vs. Action and Conflict: On Causal and Intentional Explanations in the Study of Power', Sociological Theory, 3, 2 (I985), 3I-45; and 'Power Resources and Employer-Centered Approaches in Explanations of Welfare States and Varieties of Capitalism: Protagonists, Consenters, and Antagonists', World Politics, 58, 2 (2006), I67-206; Gösta EspingAndersen, Politics Against Markets: The Social Democratic Road to Power (Princeton, NJ: Princeton University Press, 1985). 
thesis of cross-class compromise and employer interest, put forward by researchers such as Peter Swenson and Isabela Mares. ${ }^{8}$ Third, within the discipline of history, the Marxist historian Eric Hobsbawm has propagated a more confrontational account of European history, where the 'fear factor' was decisive for the development of Western European welfare states, making the Soviet Union and international, non-democratic socialism into the implicit heroes of early European welfare state development. 9 In contrast, the world society paradigm, with its origins in the 'myth perspective' within organisational studies, highlights the open-ended and contingent character of historical development, the importance of international legislative trends in world society and, crucially, the de-coupled character of reform labels and myths and their nation-level implementation. The world society perspective that concludes the article expands the analysis of MBL beyond the hitherto prevailing insular perspective on the reform as an exclusively Swedish phenomenon. The study contends that the MBL reform gained crucial momentum from the challenge to liberal democracy posed by global non-democratic socialism, i.e. from the cultural dynamics of the cold war playing out in Europe at the time.

The main body of the text applies these four perspectives to the case of the Swedish MBL reform. The goal is not to univocally refute the older lines of analysis. By definition, grand narratives - in German Meistererzählungen and in French grand récits - cannot easily be proven false or abnegated. The more modest goal here is to undermine the established narratives by relativising them and treating them as discursive components of the very history they aspire to describe. The research for this article builds on written and verbal Swedish-language sources, including mainly the internal meeting protocols of the board and executive committee of the SAP.

\section{The Swedish welfare state model and workplace democracy}

Among foreign audiences, the Swedish Model has traditionally been perceived largely as a social democratic project. ${ }^{10}$ Moreover, international observers, both ardent critics on the right and romantic devotees on the left, have frequently perceived the Swedish Model as a halfway house for Communist-type socialism. Hopeful

8 Peter Swenson, 'Bringing Capital Back In, or Social Democracy Reconsidered: Employer Power, Cross-Class Alliances, and Centralization of Industrial Relations in Denmark and Sweden', World Politics, 43, I (July I99I), 5I3-44; Capitalists Against Markets: The Making of Labour Markets and Welfare States in the United States and Sweden (Oxford: Oxford University Press, 2002); and 'Varieties of Capitalist Interests: Power, Institutions, and the Regulatory Welfare State in the United States and Sweden', Studies in American Political Development, I8, I (2004), I-29; Isabela Mares, The Politics of Social Risk: Business and Welfare State Development (Cambridge: Cambridge University Press, 2003); Thomas Paster, 'Business and Welfare State Development: Why Did Employers Accept Social Reforms', World Politics, 65, 3 (20I3), 4I6-5I.

9 Eric Hobsbawm, The Age of Extremes: A History of the World, 1914-1991 (New York: Pantheon Books, I994); How to Change the World: Tales of Marx and Marxism (London: Abacus, 20I2); and 'Goodbye To All That', Marxism Today (October I990), I8-23.

10 For contrasting perspectives, see n. I5 and 'The Nordic Countries: The Next Supermodel', The Economist, 2 Feb. 2013. 
progressive scholars, North American socialists in particular, interpreted Olof Palme's words of 'democratic socialism' as the advent of actual socialism via the ballot box. ${ }^{11}$ The terms social democracy and socialism are still often used interchangeably, neglecting the distinct liberal-democratic and anti-totalitarian roots of Swedish social democracy. ${ }^{12}$ In contemporary Swedish party politics, both social democracy and the centre-right alliance claim the label the 'Nordic Model' for themselves. ${ }^{13}$

Two central components of the traditional Swedish Model are labour market settlements based on central collective bargaining between large centrally organised unions and employers in combination with state-sponsored, universalist social policies. ${ }^{14}$ In I905, while much of Europe was in turmoil due to fierce conflicts between workers and employers, the Swedish trade union confederation, Landsorganisationen (LO), and the Swedish employers' confederation, Svenska arbetsgivareföreningen (SAF), negotiated the first nationwide central collective bargaining agreement, for engineering workshops. With the December compromise of 1906, Swedish employers confirmed the right of workers to organise freely. In exchange, the LO formally acknowledged the right of employers to manage and allocate work, and to hire and fire workers freely, a settlement that was confirmed in the historic I938 Saltsjöbaden agreement. However, this prerogative remained controversial and was the central point of contention seventy years later in the debate leading up to the MBL decision in 1976.

Throughout its history, the LO has been deeply intertwined with the SAP in manifold ways. For example, until the end of the I980s, LO labour unions and clubs could vote to become members of SAP collectively, making each individual union member a member of the Social Democratic Party as well. Since over 90\% of Swedish workers at the time were members of $\mathrm{LO}$ - which gave them access to unemployment insurance, in accordance with the Ghent model - this was an important source of members and income for the SAP.

11 Erik Åsard, 'Employee Participation in Sweden I97I-I979: The Issue of Economic Democracy', Economic and Industrial Democracy, I (I980), 37I-93, $385 \mathrm{ff}$.

12 See Sheri Berman, The Primacy of Politics: Social Democracy and the Making of Europe's Twentieth Century (Cambridge: Cambridge University Press, 2008) and 'Path Dependency and Political Action: Re-Examining Responses to Depression', Comparative Politics, 30, 4 (I998), 379-400; Hjalmar Branting, 'Ett modernt socialdemokratiskt program' (I902) and 'Demokrati eller diktatur' (I9I9), in Socialism och demokrati (Stockholm: Prisma, I970), 57-6I and I22-9. Sigfrid Hansson, Den svenska fackföreningsrörelsen, 7 th edn (Stockholm: Tiden, 1942): this book, which was core reading for internal LO union education during the entire interwar period, was written by the brother of the prime minister, Per Albin Hansson. It emphasised reformism and parliamentarianism and claimed that there was nothing democratic at all about unions in the Soviet Union (p. 404).

13 In December 20II, on the third attempt, the SAP gained the rights to the term den Nordiska modellen (The Nordic Model) as registered trademark with the Swedish Patent and Registration Office (PRV). Appeals made by the Nordic Council were turned down. In 20I2, the centre-right Alliance government then published the booklet The Nordic Way: Equality, Individuality and Social Trust (Stockholm: The Swedish Institute, 20I2), with its own reinterpretation of and claims to represent a historic Nordic Model.

14 Esping-Andersen, Politics against Markets; Bo Rothstein, Just Institutions Matter: The Moral and Political Logic of the Universal Welfare State (Cambridge: Cambridge University Press, I998). 
By the late I96os, Swedish social democracy - the SAP and the LO - was at its historical apex of power. The SAP could look back on four decades of uninterrupted incumbency in government. In I969, when the young and dynamic Olof Palme became the SAP leader, and thereby also prime minister, he briefly enjoyed approval ratings above the record electoral result of the year before, in which the SAP had received 50.I\% of the Swedish vote.

It was in the following years (the first half of the I970s) that the SAP embarked on a series of government interventions, setting the course for what Swedish conservatives later disapprovingly came to call 'the socialist decade' or 'the devastating I970s' ${ }^{15}$ These government interventions included tax hikes that resulted in record-high marginal tax rates, the expansion of and raised reimbursement levels in social insurance systems, state ownership of a small number of large industries, rapid expansion of the public sector, and a series of radical labour market reforms. By the early I99os, rises in tax, reimbursement levels and public sector expansion were to be halted and somewhat reversed, initially by the SAP itself, followed by additional reforms by non-social-democratic governments. However, the labour market reforms are still largely active today, and many have been replaced by newer and updated versions of the same law.

The I970s labour market reform spree included laws on Board Representation for Private Sector Employees (Swedish Code of Statutes, SFS I972: 262), Trade Union Representatives' Status in the Workplace (SFS 1974: 358), Labour Disputes Judicial Procedure (SFS 1974: 37I), Employees' Right to Educational Leave (SFS I974: 98I), and Security of Employment (SFS I974: I2) - all crowned by the Act on Co-Determination in the Workplace or MBL (SFS I976: 580), which is our focus here. $^{16}$

In the autumn of 1976 , the SAP was voted out of office and the reforms ceased. The SAP lost its parliamentary majority due partly to changes (from a bi-cameral to a unicameral parliamentary system) in the electoral system, to an economic crisis and to a gradual waning of left-wing momentum in society, but due mostly to the increasing unpopularity of the LO idea for a gradual socialisation of the economy via so-called wage earner investment funds (WEIFs). ${ }^{17}$ The LO initiative on WEIFs took the SAP by surprise. It eventually resulted in a rather modest reform, compared to the original

15 Johnny Munckhammar, 'The Swedish Model: It's the free market reforms, stupid', The Wall Street Journal (26 January 20II); Bernt Schiller, 'Det förödande 70-talet': SAF och medbestämmandet 1965-1982 (Stockholm: Allmänna, I988).

16 The I970s also saw fundamental changes to the Swedish labour market gender model, including the introduction in 1972 of individual income taxation for married spouses, the I974 Act on the Right to Parental Leave, the I976 decision to expand public child care, a I979 act giving parents of pre-school children the right to work 6-hour days, and the I979 Act Against Gender Discrimination in Working Life.

17 Mikael Gilljam, Svenska folket och löntagarfonderna: En studie i politisk åsiktsbildning. (Lund: Studentlitteratur, I988); Åsard, 'Employee Participation in Sweden’. 
I975 proposal for gradual socialisation: ${ }^{18}$ an extra corporate tax imposed on companies in I983, which allowed WEIFs to own a maximum $8 \%$ share of affected companies. The I99I-4 centre-right government was to liquidate the WEIFs, eradicating the issue from the Swedish political agenda. Meanwhile, the WEIF issue had become the crucial rallying call that consolidated the opposition to social democracy, which arguably ended social democratic hegemony in Sweden.

Today, the most controversial labour market reform from that era - from which, as mentioned, most laws are still in place - is not MBL, but the Act on Security of Employment, which is still the subject of left-right debate in Swedish parliament. In contrast, the MBL practices of compulsory management consultations with union representatives seem to have broad legitimacy. ${ }^{19}$ At the turn of the century, twentyfive years after the MBL reform, there had been 'no significant recent discussions or proposals on changing' MBL. ${ }^{20}$

Arguably, MBL is now a standard component of the contemporary Swedish Model, under non-social democratic governments as well. Whether this means that the MBL reform was inconsequential - a symbolic, sham reform - or that it has grown to be widely accepted is a matter of debate. Among researchers, social democratic critics gauge the reform's effects as 'modest' 21 and complain that MBL 'has not honoured the promises that were once made ${ }^{22}$ (i.e. Olof Palme's words that MBL would be the reform of the century). Others claim that the reform has socialised employers into appreciating the merits of the system. ${ }^{23}$ This article claims instead that the MBL law had broad support already when it was adopted. Meanwhile, within foreign labour market research, the myth of the socialist reform of the century lived on. At least up until the fall of the Berlin Wall in I989, Swedish MBL was perceived to have 'challenged the capitalist relations of production', 24 questioned the prerogatives of capital ownership and management decision-making,

18 Rudolf Meidner and Anna Hedborg, Löntagarfonder (Stockholm: Tiden and LO, I975); English trans.: R. Meidner, Employee Investment Funds: An Approach to Collective Capital Formation (London: George Allen and Unwin, I978).

19 Klas Levinson and Jan Wallenberg, 'Partssamverkan i offentlig verksamhet: En undersökning av svensk ledningsmodell i förändring', Arbetsliv i omvandling, 7 (2006) I-33. Cf. Henrik Berggren and Lars Trägårdh, 'Social Trust and Radical Individualism: The Paradox at the Heart of Nordic Capitalism', in The Nordic Way, I2-29, I4.

20 Annika Berg, 'Sweden', in European Industrial Relations Observatory Online, 'Thematic Feature: Works Councils and Other Workplace Employee Representation and Participation Structures', available at www.eurofound.europa.eu/eiro/2003/09/tfeature/se0309I03t.htm (last visited 27 June 2OI3).

21 Bernt Schiller, 'The Swedish Model Reconstituted', in M. D. Hancock, J. Logue and B. Schiller, eds, Managing Modern Capitalism: Industrial Renewal and Workplace Democracy in the United States and Sweden (Westport: Greenwood Press, I99I), I45-7I, I57.

22 Bo Rothstein, 'Demokratisk socialism: Ett historiskt misslyckande och dess förklaring', Häften för Kritiska Studier, I97, 5 (2008), 28-39, 3I.

23 Klas Levinson, 'Codetermination in Sweden: Myth and Reality', Economic and Industrial Democracy, 2 I (2000), 457-73.

24 James Fulcher, Labour Movements, Employers and the State: Conflict and Co-operation in Sweden and Britain (Oxford: Clarendon Press, I99I), 267-8. 
and to possess 'far-reaching ideological effects' ${ }^{25}$ Still today, in popular international left-wing debate, democratically run workplaces define contemporary visions of the Swedish Model as 'the international beacon of a democratic socialism'. ${ }^{26}$

Indeed, democratic socialism was a term that Olof Palme himself was proud to usebut how socialist was the reform actually? Correspondingly, how social democratic was it? We will now proceed to present the four aforementioned analytical cuts, discussing how each narrative highlights different aspects of the reform's development.

\section{MBL as democratic class struggle}

The predominant line of explanation for the development of strong welfare states in Scandinavia has long been the so-called power-resource approach. ${ }^{27}$ The powerresource approach claims that variations in welfare state design across the world reflect the relative organisational power and resources of national blue-collar unions and social democratic political parties. Welfare states are the result of class-based distributive struggles and partisan politics. In Korpi's analysis, the relative weakness of active resistance from the employers' side in the emergence of the Swedish welfare state is the result of the strength of social democracy. Rational actors assess each other's power resources - namely, popular support in liberal democracies - and yield to the stronger actor. Over time, non-socialist as well as socialist actors adjust their level of aspiration to fit with the actual balance of power. A strong social democracy raises its level of aspiration, and weak opponents fold. Earlier studies of the Swedish MBL decision follow this power-resource line of analysis. In Hadenius's and Bengtsson's account, rational-choice strategies of 'chicken' or 'bully' frightened or pushed the social-liberal party Folkpartiet and the agrarian party Centerpartiet into voting for the SAP's legislative proposal. ${ }^{28}$

Contrary to the power-resource analysis, this article argues that in the perception of the SAP, the two centrist parties were not merely adjusting to SAP proposals but actively taking their own initiatives on the issue of worker participation. At an SAP board meeting in June I969, shortly before a young and more radical Olof Palme was made party leader, Alva Myrdal, then head of an SAP committee on equality, complained that the initiatives of the Centre Party and their leader, Gunnar Hedlund, constituted a strategic problem for the social democrats:

It is difficult to find a party profile, when the competition on equality issues has become so strong. We cannot in any way suggest things that go as far as the [proposals of the] youth organisations of

25 Richard Hyman, The Political Economy of Industrial Relations: Theory and Practice in a Cold Climate (New York: Macmillan Press, 1989), 213-4.

26 Naomi Klein, The Shock Doctrine: The Rise of Disaster Capitalism (London: Penguin, 2008), 569.

27 Korpi, 'Conflict, Power'; 'Power Resources Approach' and 'Power Resources and EmployerCentered Approaches'; Esping-Andersen, Politics against Markets.

28 Axel Hadenius, Medbestämmandereformen (Stockholm: Almqvist and Wiksell, I983); Bo Bengtsson, 'MBL och fonderna: Två spel om ekonomisk demokrati', Statsvetenskaplig tidskrift, 73, I (I99I), I3-39. 
the centrist parties. It's almost difficult to keep pace with the unending stream of proposals from Mr Hedlund. It's a difficulty that we have. ${ }^{29}$

Alva Myrdal to the SAP board, I7 June I969

In the same vein, in the spring of I970, the prime minister, Olof Palme, complained about the difficulty of finding a political enemy for the upcoming electoral debate since the non-social democratic parties were so 'self-effacing'. ${ }^{30}$ Palme therefore instructed the party leadership to 'push the egalitarianism issue hard in simple ideological terms' ${ }^{31}$ Again, planning the 1973 election, the SAP party secretary noted that the white-collar unions TCO and SACO had radical programmes concerning work-life environment and workplace democracy, and he urged the Social Democratic Party to act within these areas and to reach out to the white-collar segment of the electorate. ${ }^{32}$

Later, in 1976, when the MBL law was eventually launched, Olof Palme spent a good part of his speech in parliament defending the law against competing claims to its origins. Particularly, he turned against the efforts of the Liberal Party, Folkpartiet, to 'portray themselves as the true originators of the democratisation of work-life'. ${ }^{33}$

In fact, as early as the mid I960s, a broad spectrum of political actors had taken initiatives on the issue of workplace democracy. In a I964 report commissioned by the Swedish employers' confederation, the SAF, economist Eric Rhenman maintained that the concept of productivity should be widened to include the work satisfaction of employees. ${ }^{34}$ In order to improve efficiency and productivity, company decision-making should strive towards a 'balance of interests' between the stakeholders: stockholders, management, employees, customers, and the public at large. ${ }^{35}$ Rhenman's thinking was developed in dialogue with American management research, and inspired by experiments in Britain and Norway with semi-autonomous work groups. ${ }^{36}$

The demands of the Rhenman report were soon mirrored in a policy brief issued by the SAF in 1965 endorsing Rhenman's idea of a balance of interests as a means of improving productivity. ${ }^{37}$ By initiating negotiations with the unions for a new framework agreement on co-operation in the workplace, by promoting reforms of the university curriculum for management studies, and by installing a

29 ARBARK I889/A/2/A/I969, I7 June I969.

30 ARBARK I889/A/2/A/I970, 28 Apr. I970.

31 Ibid.

32 ARBARK I889/A/2/A/I97I, 4 June I97I.

33 Kammarens protokoll [Protocols of the Swedish parliament] I975/76: I46, I56-7.

34 Erik Rhenman, Företagsdemokrati och företagsorganisation: Om organisationsteoris tillämpbarhet $i$ debatten om arbetslivets demokratisering (Stockholm: SAF and Norstedts, I964).

35 Ibid.

36 James G. March and Herbert A. Simon, Organizations (New York: Wiley, I958), ch. 4; Einar Thorsrud and Fred Emery, Mot en ny bedriftsorganisasjon [Towards a New Business Organisation] (Oslo: Johan Grundt Tanum, I969); Bengt Stymne, 'Eric Rhenman: Nydanare inom svensk företagsekonomi', in Lars Engwall, ed., Föregångare inom företagsekonomin (Stockholm: SNS, I995), 369-94.

37 Svenska Arbetsgivareföreningen [SAF, Swedish employers' confederation], Samarbetet i framtidens företag [Co-operation in the companies of the future] (Stockholm: SAF, I965). 
'sense of responsibility' among business managers, the SAF would be able to actively promote extended and deepened co-operation between management and employees, including improved job satisfaction for the employees. ${ }^{38}$ In 1969 , a report on the Norwegian workplace experiments - funded by a joint project of the Norwegian confederation of employers (NAF) and the Norwegian trade union federation - was translated into Swedish by the Swedish Developmental Council for Workplace Cooperation, (Utvecklingsrådet för samarbetsfragor) formed jointly by the SAF, the LO and the white-collar union, the TCO. ${ }^{39}$

In the same year as Rhenman's report to the SAF (1964), the youth organisation of the Liberal Party demanded that its party investigate the issue of work-life democracy, which resulted in a 1967 report addressing 'the tension that has emerged between the democratisation of society and the organisational structure of firms'. ${ }^{40}$ In I967, the Centre Party presented a vaguely phrased legislative proposal in parliament for the 'expansion of workplace democracy'. ${ }^{41}$ And in 1969, the Conservative Party raised a parliamentary proposal on the topic as well, arguing that the influence and co-operation of employees in the firm would be beneficial for all parties concerned and could help contribute 'a considerable stock of both specific expertise and general human experience'. ${ }^{42}$

\section{MBL as cross-class alliance and employer interest}

Cross-class alliances and employer interests are more recent contenders for the theoretical explanation of the design of Scandinavian welfare states. Archival documentation on the part of business interests shows how, historically across Europe, employers actively helped shape European welfare state insurance programmes for accident, employment and old age. ${ }^{43}$ Employers and centrist parties have assumed shared interests with social democracy concerning state-sponsored social insurance, and with unions concerning a solidaristic wage structure, maintained through central collective bargaining. ${ }^{44}$ Arguing against Korpi's power-resource model and EspingAndersen's view of a struggle between social democratic politics and recalcitrant markets, Swenson claims that the Swedish Model took shape not because of any relative employer weakness vis-à-vis organised labour and social democracy, but because of their strength. Historically, the parliamentary power of social democracy

38 Ibid. I66-222, 206, 2 IO.

39 Einar Thorsrud and Fred Emery, Medinflytande och engagemang i arbetet: Norska försök med självstyrande grupper [Empowerment and involvement at work: Norwegian experiments with self-governed groups] (Stockholm: Utvecklingsrådet för samarbetsfrågor, 1969).

40 Folkpartiet, Företagsdemokrati $i$ utveckling (Stockholm: Folk och samhälle, I967).

41 Andra kammaren (AK) [Second house of the Swedish parliament] Motion I967: 840 'Om företagsdemokrati' ['About workplace democracy'].

42 Andra kammaren (AK) Motion I969: 3I2 'Om fördjupande av företagsdemokratin' ['About the expansion of workplace democracy'].

43 Mares, The Politics of Social Risk.

44 Swenson, Capitalists against markets. 
in Sweden long relied on a cross-class alliance with the Centre Party, which in turn derived from the economic interests of organised farmers in state intervention and central wage bargaining. Meanwhile, their own broader interests led employers to refrain from any serious effort to topple social democracy from power since, Swenson contends, the compromises that shaped the Swedish Model appealed to them. ${ }^{45}$ According to Swenson's account, it was the Swedish employers and, specifically, the Swedish export industry that had an interest in accomplishing cross-firm and crosssector wage compression, by means of centralised collective bargaining, collaborative industrial relations and reformist social legislation (which removed social benefits from the wage bargain). In the late I920s, the SAF regarded itself as one of the strongest employer organisations in the world. In Swenson's account, during the formative era of the Swedish Model in the I930s, centrally organised Swedish employers coerced and corralled unions into centralising and gaining peak-level control over strikes and inter-sectorial wage structures.

The cross-class alliance and employer interest approach to the development of the Swedish Model helps make sense of the very broad involvement on the issue of workplace democracy in the I960s. During 1970 and I97I, when all three non-socialist parties submitted new parliamentary proposals on increased employee influence in firms, they stated that their motivations were to raise productivity, improve social relations and increase overall democracy in society. These goals are strikingly similar to those first put forward by the blue-collar unions and the Social Democratic Party - although social democracy eventually came to champion the issue invoking a more socialist ideological rhetoric. In Swedish parliament, only the Swedish Communist Party, Vänsterpartiet kommunisterna (VPK), was an outlier since it insisted on class struggle and wanted a workplace democracy that would lead towards the abolition of capitalism.

Why was the political support for reform of workplace democracy so broad? Research on cross-class alliances and employer interest assigns the motive for the broad support of welfare state reforms not to election tactics, as the power-resource argument would have it, but to strategic self-interest in the reforms themselves. This raises the question of why this particular perception of self-interest would emerge at this particular time. Critics of substantive rationality (i.e. the assumption that perceptions of self-interest are timeless and objective) claim that ideas matter and that even economic actors, such as firms, act in part on the basis of 'myths', socially shared mental models and evolving climates of opinion. ${ }^{46}$ Douglass North's argument bridges the divide between the rational-choice approach of Swenson and Mares and our fourth analytical cut: world society analysis. World society theory states that organisational self-interests are subject to socialisation by world society (i.e. that perceptions and priorities of self-interest mirror the times, the zeitgeist). The idea that worker participation could contribute to the economic efficiency of

45 Swenson, 'Varieties of Capitalist Interests'.

46 Arthur T. Denzau and Douglass C. North, 'Shared Mental Models: Ideologies and Institutions', Kyklos, 47, I (I994), 3-3I. 
firms - that it was rational, efficient, legitimate and 'modern' - seems to have evolved in parallel to socialist demands for workplace democracy. I now turn to the other spirit moving through Europe at the time: the Communist sentiments of I968.

\section{The fear factor: the undemocratic global class struggle}

An influential Marxist narrative sees early Western European welfare states as the result of a global rather than domestic class struggle, with the fear of Communism and the USSR as the central determinants. In Hobsbawm's account of interwar European history, reformists in Western Europe 'bought' working-class loyalty with welfare state concessions in order to avert a Soviet-style revolution. ${ }^{47}$ Throughout European history, 'fear' was the central incentive for social reform. The fear of Jacobins, of 'the force of the labouring poor', of 'social revolution everywhere', of peasant rebellion, of the workers, of the proletariat, and of the 'spectre of Communism' caused 'the rich', the reformists, the democrats, the employers, the factory-owners, the civil servants, the priests and the professors - 'the ruling classes' - to adopt social programmes. In I990 Hobsbawm went as far as lamenting the fall of the Berlin Wall and the demise of the USSR since 'capitalism could forget how to be frightened'. ${ }^{48}$ He predicted mistakenly, as it turned out - the demise of Western European welfare state reforms, for without the threat of Communism 'Why should the rich bother about anyone but themselves?'

Hobsbawm's Marxist reasoning is a lofty grand narrative, eluding empirical refutation and ethically questionable in its apologetic stance towards Communist regimes. Still, the Hobsbawmian perspective prompts the empirical question of whether fear of an undemocratic left, believed to have some degree of support from foreign state-socialist regimes, drove the MBL decision. Our focus here is on the SAP's subjective interpretation of events.

\section{The Great Miners' Strike}

Troubles with Communist activism in Swedish workplaces began in late I969 when, as in many other parts of Western Europe at the time, wildcat strikes (i.e. strikes without union approval) erupted. This was a shock for the social democratic establishment, which had grown accustomed to peaceful industrial relations ever since the 1938 Saltsjöbaden Basic Agreement between unions and employers. The Great Miners' Strike at the state-owned mining industry (LKAB) in Northern Sweden started at the Svappavaara mines, spread to other mines, eventually involved 5,00o miners, and lasted for almost two months (from early December 1969 to February 1970). The mining strike set off a wave of wildcat strikes that lasted until the mid I970s.

How did the SAP interpret the strikes? When the board of the SAP met in January I970, they perceived the strikes as neither justifiable nor representative of the workers

47 Hobsbawm, The Age of Extremes, How to Change the World and 'Goodbye To All That'.

48 Hobsbawm 'Goodbye To All That', I8-23. 
at large. There was a general consensus within the board that the strikes were not so much based on real grievances as they were grounded in radical sentiments stirred up by activists and demagogues at mass rallies - what Palme dubbed 'revival meetings'. 49 It is likely that at this time Olof Palme was privy to more detailed information from the Swedish intelligence service than were other members of the SAP board information that we shall return to.

One alleged grievance of the strikers concerned wages. Olof Palme noted that, due to the solidaristic wage structure negotiated between Swedish unions and employers,${ }^{50}$ mining wages had been capped to keep pace with wage developments in the labour market as a whole, which had caused the miners to lose their earlier status as an 'exclusive high wage group'. ${ }^{51}$ Meanwhile, the LKAB had been making record profits, leaving workers with a sense of having been fooled. Nevertheless, Olof Palme noted miners were better paid than other groups within the same industry and the miners at the striking mines were better paid than miners elsewhere.

Another grievance was the harsh and arbitrary attitude of management towards workers, which the SAP board felt was to some degree legitimate and should be addressed. On the other hand, Olof Palme noted that LKAB already had an unusually well-developed workplace democracy in the form of study circles on workplace reform, joint consultative groups and a staff newspaper - 'where Marxist-Leninists had been free to gain ground'. ${ }^{52}$

Accusations lending fire to the wildcat strike stemmed partly from the I968 novel Mine (Gruva) written by one of Sweden's most popular and widely read authors, Sara Lidman. The SAP leadership went to great lengths to try to establish whether the allegations made in the novel were founded in the reality of working life at the LKAB mines and concluded that much of the detail was not. For example, the Lidman novel depicted an ugly conflict over nails, which SAP inquiries showed was more of a singular incident involving an unusually unpleasant foreman, almost seventeen years before the wildcat strikes.

Nevertheless, despite personal prompts from Olof Palme, the LKAB management refused to defend itself in the media since it felt that journalists were too solidly against them. ${ }^{53}$ Mass media coverage of the strike was intense and even the SAP board perceived it to be overwhelmingly sympathetic to the strikers. Liberal newspapers portrayed the dire plight of workers at the state-owned industry, and reporters from the generally left-wing Swedish public service television broadcast from the mines for weeks. At the time, Swedish security services were particularly concerned by the supportive stance of Swedish public service television and radio towards the

\footnotetext{
49 ARBARK I889/A/2/A/I970, I2 Jan. I970.

${ }^{50}$ LO (Gösta Rehn and Rudolf Meidner) Fackföreningsrörelsen och den fulla sysselsättningen (Stockholm: LO, I95I).

51 ARBARK I889/A/2/A/I970, I2 Jan. I970.

52 Ibid.

53 Ibid.
} 
Communist splinter groups involved in triggering the wildcat strikes, which they concluded were receiving support from foreign powers. ${ }^{54}$

Sara Lidman, the author of the novel Mine, was a member of the parliamentary Communist Party (VPK) and a well published and celebrated author in Communist East Germany. ${ }^{55}$ Lidman spoke at the first rally of the LKAB wildcat strike, where she, to great cheers from the audience, promised to donate a token part of the proceeds from the sale of her book Mine to the strike fund. At a student support rally in the university town of Lund, she specifically targeted Paragraph 32 (formerly Paragraph 23) of the SAF Charter. The paragraph, in place since the Basic Agreement between the LO and the SAF in I906, confirmed and upheld the right of employers to lead and manage work. Lidman said Paragraph 32 marked workers as a separate 'caste', was an 'incitement to group hatred' [hets mot folkgrupp], and contradicted Paragraphs 3,6 and I9 of the universal declaration of human rights. ${ }^{56}$

At the SAP board meeting, discussions centred on the undemocratic mechanisms at play. Olof Palme questioned both the origin and the methods of the temporary strike committee, claiming that many of them had earlier lost union elections and calling them a 'salon of the refused'. ${ }^{57}$ One member of the SAP government noted an example of a wildcat strike leader educated at the Sirola Institution, the educational facility of the Finnish Communist Party. Several persons at the meeting, including Olof Palme, commented on the demagoguery and illiberal methods of the strike committee:

I am of the opinion that those mass rallies are rather undemocratic and a hindrance to discussion. The wretched man who gets up and tries to put forward an argument is clubbed down. The rally is never faced with a choice, but only with sentimental situations and forced to say yes.

Olof Palme to the SAP board, I2 January 1970

However, Palme's advice to the party was to 'lie low' and wait for people to 'come to themselves'. ${ }^{58}$ Given the pro-strike sentiments that had been kindled by the media, it would have been 'political madness' to criticise the strike, Palme contended.

54 Statens Offentliga Utredningar [Swedish Government Official Reports series], Rikets säkerhet och den personliga integriteten: De svenska säkerhetstjänsternas författningsskyddade verksamhet sedan år 1945 [National Security and Personal Privacy: The Swedish Security Services' Activities To Protect The Constitution since 1945], SOU 2002:87 (Stockholm: Fritzes, 2002), I82-8, I86.

55 Sara Lidman became well known in Communist East Germany (GDR) with her critique of the US intervention in Vietnam, Conversations in Hanoi, tr. into German in 1967 by the main GDR publisher of foreign literature, Verlag Volk und Welt. In the following years, four of her novels were published in the GDR, and in 1969 she reached the the top of the East German bestseller chart. Her books, as well as her visit to the GDR in I972, received positive reviews from the Communist Party daily Neues Deutschland. In West Germany, Lidman's novels were not published after the I950s, but in I97I she contributed to an edited volume on The Swedish Model of Exploitation, with a preface by Günther Wallraff. See Victor Pfaff and Mona Wikhäll, eds, Das schwedische Modell der Ausbeutung: Texte zum Arbeiterleben und zur Klassenstruktur im Wohlfahrtsstaat (Berlin (West): Kiepenheuer and Witsch, I97I).

56 Sara Lidman, 'Arbetskraften och de mänskliga rättigheterna: Anförande vid solidaritetsmöte för de strejkande gruvarbetarna, Lund I7 januari I970', Zenit, I6 1/2 (February I970), I-6.

57 ARBARK I889/A/2/A/I970, I2 January I970.

58 Ibid. 
Instead, a long-term response to the Communist activists' challenge began to take shape. This article argues that SAP's new strategy was bifurcated. On the one hand, the SAP never left its ideological tradition of reformism and defence of representative liberal democracy. At the same time, the SAP now became much more rhetorically active in trying to take on the radical left on common issues - including demands for more workplace democracy and a range of symbolic issues in foreign policy. ${ }^{59}$ Already in this first response to the new wave of Communist activism at workplaces, the strike crisis was interpreted as a crisis of democracy in the workplace:

When this is over, we have to bring this issue up - not the conditions at LKAB, but the whole question of democracy in the workplace.

Ingvar Svanberg, to the SAP board, I2 January 1970

However, the issue of reforming and improving workplace democracy was not forced onto the SAP agenda by the wildcat strike events. The issue had been making progress within Swedish social democracy (LO and SAP) at least since the early I96os. It was a key ingredient of Olof Palme's inaugural speech as new party leader in the summer of I969. Indeed, one biographer claims that Palme's personal passion for the issue of workplace democracy was awoken already in the late I940s, during his studies at Kenyon College in the USA. ${ }^{60}$

The internal deliberations of the SAP board suggest that the Great Miners' Strike may however have given the issue of workplace democracy increased impetus and helped to shape it. To some extent, the problem of wildcat strikes became paired with the solution of reformed workplace democracy. ${ }^{61}$ In November of the same year, when Olof Palme drew up the overarching party strategy for the upcoming elections, workplace democracy was a high priority. ${ }^{62}$ The plan was that the blue-collar trade union federation, the LO, would launch the problem of workplace democracy as the 'big issue' at their next conference, and the SAP would catch on to the LO's demands. ${ }^{63}$

\section{Concern over local LO representatives}

Was the MBL reform actually driven by the SAP's fear of global Communism, as an analysis from a Hobsbawmian perspective would have it? Since I968, the Swedish Security Service regarded Communist activism that had foreign support and

59 On the Palme governments' progressive foreign policy as a strategy to accommodate the left-wing trend among Swedish youth, see Aryo Makko, 'Sweden, Europe, and the Cold War: A Reappraisal', Journal of Cold War Studies, I4, 2 (2012), 68-97, 68-70.

60 Henrik Berggren, Underbara dagar framför oss: En biografi över Olof Palme (Stockholm: Norstedt, 20Io), I29-36, 427, 54I. For the contrasting view that Palme had little personal interest in workplace democracy, see Kjell Östberg, I takt med tiden: Olof Palme 1927-1969 (Stockholm: Leopard, 2008), $395-6$.

61 On temporal sorting or 'garbage-can decision-making', see Michael D. Cohen, James G. March and Johan P. Olsen, 'A Garbage Can Model of Organizational Choice', Administrative Science Quarterly, I7, I (I972), I-25.

62 ARBARK I889/A/2/A/I970, 26 Nov. I970.

63 Ibid. 
entertained links to broader student protests as the main domestic threat to Swedish democracy. ${ }^{64}$ They concluded that left-wing extremists with foreign support were targeting specific, strategically important workplaces, such as heavy industry, schools and the media. The extremists had their roots in and remained influential within the so-called FNL groups, a very broad and diverse radical movement that had formed in I966 under the slogan 'USA out of Vietnam'.

At SAP board meetings, concern over Communist-led, anti-democratic activism in the workplace was indeed a recurring topic. However, at no point in SAP board meeting protocols are the radical activists addressed as a threat to either national security or overall democracy. Rather, the focus of the SAP board's internal deliberations was squarely on the well-being of the local union representatives.

In February 1973, the SAP executive committee held a small hearing with a few union and party functionaries from around the country regarding the workplace activities of the Communist splinter group Kommunistiska Förbundet Marxist-Leninisterna revolutionärerna (KFML-r). ${ }^{65}$ KFML-r (actually KFML/SKP) activities in Stockholm were considered to be 'less dramatic' than those on the West coast, but still earned a special report, which will be quoted at some length since it gives a vivid image of the societal upheaval facing social democracy at the time. ${ }^{66}$ The oral report claimed that, at the Stockholm city social services, the management had been sidelined by revolting employees, and replaced by weekly mass rallies, which were convened during working hours to decide on how work should be organised. A representative of the local Stockholm SAP reported to the SAP executive committee:

The meetings of the Stockholm Social Workers' Association usually assemble 400-500 participants. At these mass rallies it is also decided who will benefit from social care. It is those who are 'treatment motivated' i.e. susceptible to the argument that it is society's fault, not their own, that they have 'slipped'. This of course means that many do not receive the treatment that they would need and could have. Since this treatment ideology has been applied, several of the county's health institutions have had to close because of low occupancy. This is one of the reasons why many people in need of care are drifting around in the city centre. They are not regarded as 'treatment motivated' ...

64 Statens Offentliga Utredningar, Rikets säkerhet, I82-8.

65 ARBARK I889/A/2/A/I973, I4 Feb. I973.

66 The two groups KFML-r and KFML/SKP shifted their politics somewhat over time, and both contemporaries and later historians have had trouble keeping the groups apart - as the protocols of the SAP board show. KFML-r was a I970 splinter group of the splinter group KFML (later renamed Sveriges Kommunistiska Parti, SKP), that had broken out of the parliamentary party Sveriges Kommunistiska Parti, SKP, when in I967 SKP in a symbolical move away from the Soviet Union renamed itself Vänsterpartiet kommunisterna (Vpk). By I973, the young little activist group KFML-r had $\mathrm{I} 7$ full time functionaries in the Gothenburg area, and had bought a cinema to run their activities from. Originally, the KFML-r, which dominated the Gothenburg area, promoted wildcat strikes, and wished to undermine the established unions, while the aim of KFML (later SKP), which had its centre in Stockholm, was instead to take over the unions from within. KFML organised study circles based on the booklet 'Gör facket till en kamporganisation!' ('Make the unions into combat organisations!'), which they published in their own publishing house, Oktober. Both KFML and KFML-r were active in the campaigns against Paragraph 32. Over time, the splinter groups were suspected by the Swedish security police to have alternating sources of foreign support; economic support from China, and economic and educational support from the Soviet Union, via East Germany. See Statens Offentliga Utredningar [Swedish Government Official Reports series] Övervakningen av SKP-komplexet, SOU 2002:93 and Rikets säkerhet, SOU 2002:87 (Stockholm: Fritze, 2002). 
The group that constitutes the core of KFML-r has attracted a tail of people who are generally radical but don't know quite what this is about. Among them are also people from our party.

Jan-Olof Persson, Stockholm SAP representative, to the SAP executive committee, I4 February I973

The SAP executive committee was convinced that very few employees were aware that these actions were organised and planned by a core of KFML-r activists. When Olof Palme met with the SAP board two days later to outline the tactics on how to confront the activism at workplaces, he specifically emphasised that there was to be no general 'witch-hunt' of radicals. ${ }^{67}$ Palme wanted to prevent Communist activists being able to paint themselves as martyrs, he said. In defining the problem of Communist activity in the workplace, the SAP board was particularly concerned with local union functionaries and chairmen. ${ }^{68} \mathrm{~A}$ union representative reporting to the SAP executive committee stated that local functionaries felt 'personally heavily exposed and persecuted'. According to the reports reaching the committee, 'lies and systematic defamation of local union functionaries' were a pervasive aspect of KFML-r activities. ${ }^{69}$

\section{How MBL addressed the Communist threat}

The bottom line of discussions at SAP board meetings was that social democracy should better prepare those who had to take on the direct confrontations with Communist activists at workplaces, namely the local union functionaries, and give them moral support. ${ }^{70}$ Looking back on the MBL decision today, this study suggests that the reform accomplished this in three ways: first, MBL symbolically addressed the broader left-wing opinion by feeding it a 'radical' reform - although the reform in its technical detail was arguably quite liberal, not socialist, since it did not alter ownership relations. Centrally, lawmakers yielded symbolically to Communist activist attacks on Paragraph 32 of the statute of the Swedish employers' confederation (SAF), which laid down managers' prerogative to freely hire and fire workers, and lead and direct work, by phrasing Paragraph 32 of the MBL law as a counterpoint. In Olof Palme's words, the MBL decision was a 'historic day', when Paragraph 32 of the SAF charter was made to "vanish into history'. ${ }^{71}$ In contrast to Paragraph 32 of the SAF charter, Paragraph 32 of the MBL states that when employers reach a collective bargaining agreement with unions, they must also enter a collective bargaining agreement concerning employee co-determination, or medbestämmande,

67 ARBARK I889/A/2/A/I973, I6 Feb. I973.

68 ARBARK I889/A/2/A/I973, I4 Feb. I973.

69 On so-called Zersetzungsmassnahmen, or 'decomposing measures' towards individuals, see Klaus Behnke and Jürgen Fuchs, Zersetzung der Seele: Psychologie und Psychiatrie im Dienste der Stasi, 3rd edn (Hamburg: Europäische Verlagsanstalt, 20I0).

70 ARBARK I889/A/2/A/I973, I6 February I973.

71 Kammarens protokoll [Protocols of the Swedish parliament] I975/76: I46, 2 June I976, Arbetsrättsreform m.m. [Labour law reform etc.]. 
which encompasses 'the conclusion and termination of contracts of employment, the management and distribution of work, and the operation of the activity in general'. ${ }^{72}$

Second, the MBL put this new weapon for the promotion of employee interests directly into the hands of established unions. In West Germany, the I972 law on workplace co-determination procedures stipulated that participants were to abstain from all forms of party politics in the workplace - a route that a 1975 Swedish state investigation on propaganda in workplaces advised against, since, they held, it would contradict the freedom of opinion formation principle laid down in the Swedish constitution, and in practice would disadvantage the parliamentary parties rather than Communist activism. ${ }^{73}$ In accordance with the recommendations of the state investigation, the I976 MBL law did not banish politics from the workplace, but assigned co-determination rights only to the representatives of those unions in the workplace that already had a collective bargaining agreement with the employer. ${ }^{74}$ In effect, MBL made the elected representatives of established unions the ombudsmen of the workers, with the legal clout to force employers to inform, discuss and negotiate before making decisions. By design, the co-determination process was protected from the illiberal dynamic of mass meetings, coups and minority takeovers.

Third, by legislating on workplace democracy, MBL education became the object of parliamentary funding. The need to educate local union representatives to make better use of co-determination arrangements in the workplace had been voiced by both white-collar and blue-collar unions ever since the early i960s. ${ }^{75}$ After the strikes of I970, education also became a means to counter workplace radicalism. At a SAP executive committee meeting in late I970, three SAP party secretaries, one current and two former, argued that local SAP functionaries and local LO representatives must be trained to be able to take on the debate with KFML activists in the workplace. ${ }^{76}$ The problem of Communist radicalism became coupled with the MBL law as its solution. ${ }^{77}$

When the MBL law replaced the earlier collective agreement on work councils, education about the MBL law was tucked under the umbrella of the Swedish state's subsidies for popular adult education, folkbildning. The formula 'free and voluntary', guiding Swedish state subsidies for folkbildning since 1944, meant that MBL education was to be organised independently by the unions themselves, who also decided the

72 'Lag (I976:580) om medbestämmande i arbetslivet' ['Law on Codetermination in the workplace'], Svensk författningssamling [Swedish Book of Statutes] (Stockholm: Fritzes).

73 Statens Offentliga Utredningar [Swedish Government Official Reports series] Politisk propaganda på arbetsplatser [Political Propaganda in Workplaces], SOU 1975:27 (Stockholm: Fritze, 1975).

74 In 2005, EU directive 2002/I6 forced Sweden to revise MBL to extend the right of information to all unions represented at a workplace (i.e. not only to unions with collective agreements with the employer). See Jenny Lundberg, The Impact of the Information and Consultation Directive on Industrial Relations in Sweden, EIRO (European Industrial Relations Observatory), document ID SE07I0029Q.

75 TCO, Tjänstemännen och företagsnämnderna (Stockholm: TCO, I966). LO, Solidariskt medbestämmande: Rapport till LO-kongressen (Stockholm: LO, I976).

76 Torsten Nilsson, Sten Andersson and Sven Aspling, see ARBARK i889/A/2/A/I970, 24 Nov. I970.

77 Cohen et al., 'A Garbage Can Model'. 
educational content. ${ }^{78}$ In 1976 the LO decided to prioritise local self-organised study circles of ordinary union members, guided by centrally produced study materials, with the goal of reaching 200,000 LO members (i.e. roughly one tenth of the overall membership) per year. ${ }^{79}$ The aim of the new 'Basic course on union rights' (Facklig grundkurs) was to ignite societal change through raising the participants' political consciousness and activity. ${ }^{80}$ Study materials emphasised formal liberal-democratic meeting techniques: how to establish a written agenda and keep a list of speakers, how to set up a correct voting procedure for multiple competing propositions, how to refer an item to the preparatory body for further investigation, postpone a decision or adjourn a meeting, and so on. ${ }^{81}$ However, the study materials also advocated 'democratic socialism' and a 'democratic planned economy', in accordance with the LO's WEIF proposals launched in $1976 .{ }^{82}$ Members were urged to 'participate in the efforts to propel a socialist transformation of society' and 'fight against the anti-socialist ideology produced by firms and the mass media' ${ }^{83}$

During the years after the MBL decision, state funding for study circles more than doubled, and state subsidies of residential colleges for adult education (folkhögskolor) more than tripled. ${ }^{84}$ Here, local union functionaries would not only learn how to use the letter of the new law in negotiations with employers, but also had the possibility to read and discuss Marxist classics, arming them for ideological confrontations with the radical left-wing activists. ${ }^{85}$ In sum, despite the social democrat claim to have championed the MBL reform in the face of non-socialist resistance, the article maintains first, that the reform had broad and longstanding non-socialist support, second, that its implementation in fact served to strengthen liberal democracy and cross-class compromise against their antagonists, and third, that the radical rhetoric accompanying the reform came to influence the self-understanding as well as the international image of social democracy's position in relation to socialism in the cold war.

\section{Worker participation as cold war trend}

This brings us to our fourth analytical cut: world society theory. According to world society theory, welfare states are not the product of domestic evolution alone, but are

78 The traditional beneficiaries of Swedish state subsidies for popular adult education (folkbildning) have been the trade union movement, the temperance movement, the women's movement, the farmers' movement, and the Free Church Movement, through their respective study associations and the adult colleges that they have owned or been associated with.

79 LO, Fackliga studier: Sammanfattning av studieutredningens (STULO) rapport. (Stockholm: LO, I976).

80 Ibid. $35-7$.

81 Centrala Fackliga Studiekommittén (CFS), Facklig grundkurs: Grundmaterial. (Stockholm: ABF, LO och Brevskolan, I978), 54-9.

82 CFS, Facket $i$ samhället: Tillvalsmaterial till facklig grundkurs. (Stockholm: ABF, LO och Brevskolan, I978).

83 Ibid. I24.

84 Statsliggaren [The State Ledger] (Stockholm: Fritze, I975/76-I985/86).

85 On education as LO's main tool of identity policy during the interwar period, see Jenny Jansson, 'Manufacturing Consensus: The Making of the Swedish Reformist Working Class', PhD dissertation, University of Uppsala, 2012. 
shaped by the international influences of world society, especially when it comes to formal legislation and its myth and ceremony. These influences travel by the means of 'myth', i.e. the reputation or impression that a specific type of organisational model or reform is modern and progressive and that it contributes to common, overarching goals of different types of modernity, such as socio-economic development, human welfare, justice and equality. ${ }^{86}$ For example, world society studies have shown how state planning for economic growth spread as an international trend during the post-war era. ${ }^{87}$ Diverse examples include the formal organisation of education, the adoption of national parks, and the establishment of laws against child labour. In the world society account of organisational globalisation, labels and formal models (i.e. 'myths') spread better than actual practices and implementation forms (i.e. policy). States adopt seemingly similar organisational reforms as fashion, but their actual content, policy and practice are 'de-coupled' from labels and differ between countries.

In contrast to policy diffusion studies, world society theory poses the 'big' question: how is modernity shaped and expanded across the globe? One traditional reply has been that strong nations act as international 'paragons of virtue'; the poor and weak copy the rich and strong. ${ }^{88}$ However, defenders of world society theory object that international isomorphism (i.e. that countries tend to adopt policies with similar outer shape or labels) is no mirror image of international hard power relations. When it came to worker participation, the status as international paragon of virtue was contested, with both Western liberal-democratic models and socialist proposals as contenders. This study highlights how the competition between these models and political identities drove the worker participation issue forward. Arguably, it was the cultural cold war itself that intensified the push for reform. The SAP found itself squeezed between demands on workplace democracy from both left and right. It solved the issue by making an ingenious and original compromise that defended democracy against its antagonists, while claiming ownership of the reform for itself and invoking the reform rhetorically to try to strengthen its left-wing credibility.

In the existing research on the Swedish MBL reform, the international setting of the MBL reform has rarely, if ever, been mentioned. ${ }^{89}$ It is as if Sweden invented the wheel on its own. If worker co-determination policies have spread via world society, as suggested by world society theory, legal reforms should appear in international 'waves' clustered in time. Incidentally, in the case of worker participation legislation in Europe, they do. When compared internationally, the Swedish MBL reform appeared at the tail end of a wave of similar Western European reforms: in I97I

86 John W. Meyer, 'Globalization: Sources and Effects on National States and Societies', International Sociology, 2000, I5, 233-48, 234.

${ }^{87}$ Hokyu Hwang, 'Planning Development: Globalization and the Shifting Locus of Planning' in G. S. Drori, J. W. Meyer, F. Ramirez, and E. Schofer, eds, Science in the Modern World Polity: Institutionalization and Globalization (Stanford, Calif.: Stanford University Press, 2002), 69-90; John W. Meyer, John Boli-Bennett and Christopher Chase-Dunn, 'Convergence and Divergence in Development', Annual Review of Sociology, I (I975), 223-46.

88 Meyer et al., 'World Society and the Nation State', I64.

89 One exception is the journalist Svante Nycander, Makten över arbetsmarknaden: Ett perspektiv på Sveriges 1900-tal (Stockholm: SNS, 2002). 
the Netherlands adopted an Act on Works Councils. In 1972 the Federal German Republic adopted its Works Constitutions Act, the Betriebsverfassungsgesetz; in I973 Austria adopted the Works Constitution Act, and Belgium issued a Royal Decree demanding that economic and financial information be supplied to works councils; and in 1974 Luxemburg adopted a law on joint works committees in private sector companies. Furthermore, the worker participation issue was high up the agenda of both the International Labour Organization (ILO) and the European Commission, providing ample fora for transnational communication among experts on the issue. Within the ILO, the Yugoslav model received much attention, while West Germany was particularly active in its efforts on the issue within the European Economic Community (EEC).

We now return to the question posed initially in this text: was the Swedish MBL reform inspired by Sweden's capitalist neighbours or by Communist reforms, such as the Yugoslavian worker-participation model? From the archives of the Swedish $\mathrm{LO}$, it is clear that the organisation did keep a close eye on legislative initiatives in other countries. ${ }^{90}$ Strikingly, though, the LO investigation on workplace democracy, Företagsnämndsutredningen, showed no interest at all in Communist models, which it must have regarded as irrelevant. In the archives of the investigation, texts on Yugoslavian worker participation are rare. The one example found originates from France and was sent to the LO by a French union. Outwardly, LO rarely referred to worker-participation models in other countries, and when they did, the examples were all from Western Europe. ${ }^{91}$

Meanwhile, in the Swedish public sphere at the time, social democracy faced fierce competition on the issue of workplace democracy, both from the left and from the right. A plethora of actors were involved in the debate, from parliamentary parties and the scientific experts of SAF (the employers' confederation), left-wing social democratic intellectuals, fringe Communist splinter groups and radical activists such as Sara Lidman. As this article has described, this variety of initiatives, in turn, drew inspiration from transnational ties to organisations, movements, experts and scientists in other countries. For example, the influential expert of the SAF, Rhenman, drew inspiration from developments within American organisational theory as well as Norwegian practical experiments with alternative models of work organisation. Rhenman's fiercest critics, on the other hand, were socialist and part of the emerging New Left in Sweden, which used the Yugoslav example as a basis of comparison for increasingly radical demands. For the New Left, a strengthening of workplace democracy was but a first step towards the socialisation of the economy, and a type of socialism that would be more radical than existing Eastern European models. ${ }^{92}$

90 Landsorganisationen (LO), Handlingar rörande företagsnämndsverksamhet [Documents relating to work council activities], ARBARK 2964/F/20.

91 Cf. LO, Industrial Democracy: Programme Adopted by the 1971 Congress of the Swedish Trade Union Confederation (Stockholm: LO, I972).

92 Göran Therborn, ed., En ny vänster [A New Left] (Stockholm: Rabén and Sjögren, I966), I69-96, 92. Cf. Leif Backlund, 'Medbestämmande och Europas självständighet', Tiden (Stockholm: SAP, I969), 6I, 587-9I. 
Concurrently with the MBL decision, intellectuals with an SAP affiliation and progressives just to the left of the SAP took much interest in Yugoslavia, pushing the party towards an increasingly radical rhetoric. ${ }^{93}$ Furthermore, once the MBL reform was in place, the SAP and the LO acted to promote its image as a radical but also specifically social democratic reform. In the educational programme of the $\mathrm{LO}$, the MBL reform was portrayed as a step towards democratic socialism and a planned economy.

Were the details of MBL modelled on the legislation of other European countries? The answer is largely negative. The policy-making experts within both SAP and LO indeed took an interest in the legislation efforts of other Western European countries, including the aspiring international paragon of worker participation, West Germany. Since the mid I95Os, the LO had been collecting information on legislative initiatives in other Western European countries; ${ }^{94}$ hence, it had clear information that national legislation was under way in many countries across Western Europe. Nevertheless, the design of the Swedish MBL came to build considerably on the existing Swedish central collective agreement on workers' councils, Företagsnämnder, in place since I946 and renewed in I966. The Swedish MBL regulated by law what had earlier been subject only to collective agreements. The Swedish tradition was to encourage advisory consultations between employers and union representatives. In contrast to West Germany, for example, Swedish unions had traditionally been reluctant to accept actual co-responsibility for decisions (the very definition of what in Germany is termed Mitbestimmung), fearing co-option and conflicts of loyalty.

In sum, as predicted by world society theory, Sweden's initiative was not unique but was part of an international trend to legislate on worker participation. Moreover, in accordance with world society theory, the content and implementation of the law was de-coupled from that trend; that is, the letter of the law was shaped by national traditions and circumstances, rather than international policy diffusion. The SAP's presentation of MBL catered to an emerging international 'myth' or belief in world society at the time, which heralded worker participation as a useful tool for achieving overarching norms of human development, egalitarianism and progress.

\section{A socialist or liberal-democratic reform?}

The main thrust of the Swedish MBL is the right to information and pre-emptive advisory negotiation. The MBL set forth a right to information that obliges employers to keep their employees continuously informed about issues pertaining to the employer-employee relationship. This includes personnel policies, hiring, firing, the management and distribution of work, and the company operations in general, such as making larger organisational changes, investments and relocation, as well as letting

93 See, e.g. Bo Södersten, Den svenska sköldpaddan: Politiskt, ekonomiskt, personligt ur ett socialdemokratiskt perspektiv (Stockholm: Rabén and Sjögren, I975); Bengt Abrahamson, Exemplet Jugoslavien och den svenska debatten om löntagarfondstyre (Stockholm: AWE/Geber, I976); Bogdan Denitch, 'Det jugoslaviska exemplet: Självstyre och arbetarråd', Tiden (Stockholm: Sveriges Socialdemokratiska Arbetarparti, 1974), 66, I33-45.

94 See Landsorganisationen (LO), Handlingar rörande företagsnämndsverksamhet; also Villy Bergström, 'Löntagarfonder för demokrati', Tiden (Stockholm: SAP, 1975), 67, 363-73. 
unions look at the company books. MBL obliges employers to take the initiative on so-called 'MBL-negotiations' (i.e. to proactively consult and discuss with the union representative on the matters above) before any decision is taken. In sum, MBL made pre-emptive advisory negotiations compulsory. Additionally, it broadened the scope of negotiations and the unions' right to information to include the management prerogatives defined in the controversial Paragraph 32 of the SAF statute, providing for the right of employers to lead and manage work, and hire and fire staff.

Does this mean that Swedish workplace democracy is weak? The verdict depends partly on our ideological assumptions. Assuming that labour market relations are essentially a democratic class struggle over zero-sum resources, which is a traditional Marxist perspective, the Swedish MBL must be considered weak. In the years after its adoption, the Swedish MBL was derisively dubbed the 'honk before running over' law since it did not oblige employers to heed employee advice, but only to inform and hear unions out before deciding.

Since then, analytical concepts of power have emerged within social science that may give us a different perspective on the reform. Theories of deliberative democracy would highlight instead the potential for communicative power that the MBL bestows on employee representatives. ${ }^{95}$ Arguably, the $\mathrm{MBL}$ gives union representatives a formal framework for communicative action towards managers, albeit with the crucial caveat that union representatives cannot bring debates into the public sphere, since their access to company information is conditioned on professional secrecy, as defined in MBL. In other words, from the perspective of liberal communicative democracy, the reform would probably be regarded as rather significant.

\section{Conclusions}

What can the MBL reform tell us about the history and development of the Swedish Model? The article has argued that contrary to the dominant power-resource interpretation of the advent of the Swedish welfare state, on the issue of workplace democracy, the SAP was not really pushing the centre-right parties towards the Swedish Model; rather the reverse was just as true. White-collar unions, the SAF, and the Centre and Liberal Parties were all putting forward their own proposals. The MBL was not just a social democratic reform project but also the project of a much broader cross-class alliance and even of employer interest. Nevertheless, this study wishes to transcend current analytical frameworks of how cross-class alliances and employer interests have contributed to welfare state growth by moving from a focus on rational self-interest to the level of discourse and identity. How did this particular perception of self-interest arise at the time it did? The article has suggested that the zeitgeist in Sweden can be traced to the international level, where a wave of legislation on workplace democracy swept across Europe at the time.

Furthermore, we have discussed the impact of international non-democratic Communist activism. The argument presented here is that the fear of Communism

95 Cf. Jürgen Habermas, 'Drei normative Modelle der Demokratie', in Die Einbeziehung des Anderen (Frankfurt: Suhrkamp, I996), 277-92. 
did not propel the Swedish reform; however, once the reform was under way, it became coupled with the contemporary political problem of non-democratic disruptions in the workplace. The strategy of Swedish social democracy was bifurcated: the radical narrative of the reform - its myth and ceremony - catered to a radicalised public opinion that demanded more egalitarianism in society. Concurrently, the design and implementation of the reform strengthened established unions in the workplaces, at the expense of radical activism.

In conclusion, the case study offered here answers to the call for more detailed, qualitative case studies of the impact of world society trends on the national level. ${ }^{96}$ Particularly, it places the development of the Swedish Model in the context of the cultural cold war over hearts and minds in Europe. For Sweden, the MBL decision may mark the pivotal point in time when the SAP came to adopt a more radical rhetoric and made Sweden known across the globe as an experiment in 'democratic socialism'.

\section{Les Origines et la mythologie du modèle suédois de la démocratie au travail}

En I976, la Suède adoptait une loi sur la démocratie au travail, présentée par le gouvernement socialdémocrate comme la 'réforme du siècle'. Que nous apprend cette réforme sur l'histoire du modèle suédois et sur la manière dont il a été revu au début des années soixante-dix, sous le premier ministre Olof Palme ? Cet article compare quatre narratifs majeurs du développement des États providence, et avance que les narratifs dominants du modèle suédois constituent en euxmêmes des mythes influents. Selon l'auteur, la réforme de la démocratie au travail en Suède, en dépit de sa réputation mondiale d'archétype du 'socialisme démocratique', constituait en fait un vaste compromis entre différentes classes sociales, dans la lignée d'une vague paneuropéenne de réformes bénéficiant d'appellations similaires. Cette réforme a en outre servi à protéger les lieux de travail contre l'activisme communiste. L'auteur se fonde ici sur les procès-verbaux de réunions internes du comité de direction et du comité exécutif du parti social-démocratique suédois.

\section{Ursprung und Mythen des Schwedischen Modells der Demokratie am Arbeitsplatz}

Schweden verabschiedete I976 das Mitbestimmungsgesetz, das von der sozialdemokratischen Regierung als 'Jahrhundertreform' gefeiert wurde. Welche Erkenntnisse über die Geschichte des Schwedischen Modells und dessen Überarbeitung in den frühen siebziger Jahren unter der Regierung von Ministerpräsident Olof Palme kann uns diese Reform vermitteln? In diesem Beitrag werden vier bedeutende Narrative über die Entwicklung von Wohlfahrtsstaaten verglichen, wobei die dominanten Darstellungen über das Schwedische Modell für sich genommen als einflussreiche Mythen betrachtet werden. Dabei wird die Hypothese aufgestellt, dass es sich bei der schwedischen Reform zur Demokratie am Arbeitsplatz - die weltweit als Maßstab des 'demokratischen Sozialismus' besonderes Ansehen genießt - letztlich um einen breiten klassenübergreifenden Kompromiss handelte. Sie folgte auf eine paneuropäische Welle von Reformen, die mit einem ähnlichen Etikett versehen wurden. Zudem fungierte die Reform als Schutz vor kommunistischem Aktivismus am Arbeitsplatz. Als Quellenmaterialien legt der Beitrag die internen Sitzungsprotokolle des Vorstands und des Exekutivausschusses der schwedischen Sozialdemokratischen Partei zugrunde. 